\title{
Trying to get MPs interested in science
}

\section{from David Spurgeon, Ottawa}

Five years ago, when interest in science policy was still running high among some Canadian scientists and politicians, the Association of the Scientific, Engineering and Technological Community of Canada (mercifully shortened in popular parlance to SCITEC) was formed. It was established in response to the frustrated complaint of a member of the Senate Special Committee on Science Policy that he could not determine which among the many voices really spoke for science in Canada. It was to become a sort of parliament of science', and one of its main purposes was to initiate a dialogue with members of the real Parliament in Ottawa.

Since those palmy days, science policy discussions have fallen upon such bad times that when SCITEC recently held its fifth annual meeting, one parliamentarian summed up the present situation thus:

"Science policy is the biggest nonquestion in the House of Commons. Nobody even knows how to frame a question. On occasions I have been asked to please ask a question of the science minister. Nobody even knows he's there, and a politician can stand anything except not being noticed."

Max Saltsman, New Democratic Party member, had been invited as a member of a panel held after the annual meeting to initiate between parliamentarians and scientists, just the kind of dialogue both have found lacking in the past. The report of the outgoing association president, $\operatorname{Dr}$ M. P. Bachynski, said it was SCITEC's intention "that this become a continuing dialogue which could lead to a more formalised vehicle for such interaction -an association of scientists, engineers and parliamentarians."

This hope reflected an earlier one, expressed years ago when the organisation had just got going, that an in- formal club might be formed for the same purpose. Under the circumstances, the hope seemed rather a forlorn one.

But at least a dialogue had begun. Most of the MPs on the panel, of course, might have been expected to be interested, because they had scientific or engineering backgrounds. They included Harvie Andre, a Progressive Conservative MP with a PhD degree in chemical engineering, formerly an associate professor in that discipline; Frank W. Maine, Liberal MP and former Athlone Fellow, who holds a $\mathrm{PhD}$ in organic chemistry and was previously director of research and development in a manufacturing company; and Ross Milne, Liberal, an engineer with a master's degree in environmental control.

$\mathrm{Mr}$ Andre was particularly concerned with the present state of public policy relating to science: he called it "a hell of a mess." Recalling the great interest in science policy during the 1960 s, he said this had led to an uncomplimentary comparison of Canada's performance with that of other industrialised countries. A whole series of studies had shown that Canada spent proportionately less on research and development than most industrialised nations, and spent less on such activities in industry and more on in-house government research.

The response of the federal government was to create the Ministry of State for Science and Technology (MOSST), but that did not solve the problems, Mr Andre said. "In the four years that department has been in operation, in every way, in each of those [four] areas of comparison, we are worse off." Canada now spends a smaller percentage of its GNP on science and technology; in spite of the MOSST's contracting-out policy, the proportion of in-house research and development has increased rather than decreased (from 65 to $72 \%$ of the total); and the percentage of the GNP spent on research and development by industry has about halved.

Mr Andre said he was not implying this was all the MOSST's doing. He felt

\section{Clearing house for cancer epidemiology}

THE International Agency for Research on Cancer of the World Health Organisation in Lyon is collaborating with the Deutsches Krebsforschungszentrum in Heidelberg in setting up an international clearing house for the exchange of information on epidemiological studies in cancer. Requests are just going out to epidemiologists to complete a standard form describing the on-going projects. It is hoped that in this way an Annual Directory can be compiled and also that participants can be supplied with current information at any time. The sponsors believe that this may, among other things, help cut down the number of occasions on which similar studies cannot be campared because some relatively minor procedure was not carried out in all cases. rather that the ministry lacked muscle to accomplish its objectives. He would like to see it obtain that power-if not, it should be abolished. "It is now a convenient screen to divert attention away from problems and it allows the government to say they are curing the problems."

Dr Virginia Douglas, immediate past president of SCITEC and a panel member representing science, said politicians and scientists both seem to agree that they must get together, yet they also seem to agree that, after endless studies, "we've achieved little communication."

She suggested the trouble was that the two groups work from different assumptions and use different techniques to solve problems. She said the mission-oriented approach is understandably attractive to politicians, but many others are not convinced that a direct, simple-minded approach will solve society's problems. Scientists are being asked to provide simple answers for complex questions-sometimes insoluble ones. And not everything can be subjected usefully to cost-benefit analysis, as politicians would like.

The attempt to control science and put it to work through bureaucracy does not seem to be working, she said, and it endangers the productivity of science. She pleaded with the politicians not to put scientists into a bureaucratic strait-jacket and not to put them into the position of being adversaries. And she said the time has come to stop talking abstractly about policies and start adopting a case approach to the solution problems.

Perhaps one of the best indications of the parlous state of relations between SCITEC and the federal government was revealed in Dr Bachynski's report on SCITEC's attempt to obtain approval of a plan to build a house of science and technology (HOST) to bring together the mostly indigent scientific societies centrally in Ottawa.

The MOSST had never answered the proposal officially, Dr Bachynksi said. But unofficially, the indications were tha the ministry would not support it as SCITEC wanted. "The impression I have is that the ministry would be glad to support such a project as long as it didn't cost the government any money."

Money, of course, was exactly what SCITEC and the other societies needed. But, according to Dr Bachynski, the ministry seemed to think that it would be a difficult idea to sell politically, because all kinds of other groups might then want similar favours and the electorate would not see why scientists should be treated any differently from anyone else. A perfectly understandable view, one is tempted to add. 